\title{
Police and judicial efficiency in Colombia
}

\author{
Ángel David Ramírez Romero \\ Universidad de los andes \\ Colombia
}

Héctor Daniel Martínez Duarte

Universidad de Pamplona

Colombia

Jennifer Katherine Rincón Amaya

Universidad de Pamplona

Colombia 


\title{
Police and judicial efficiency in Colombia ${ }^{1}$
}

\author{
Ángel David Ramírez Romero*(iD) , Héctor Daniel Martínez Duarte**iD \& Jennifer \\ Katherine Rincón Amaya**iD) \\ * Universidad de los Andes - Colombia \\ ** Universidad de Pamplona - Colombia
}

\begin{abstract}
According to socioeconomic theories of criminal behavior, crime rates can be reduced by increasing the probability and severity of punishment. In this line, the public force and the judicial sector play an important role depending on their performance. This document analyzes this performance for each department of Colombia in 2018. Using the technique of Data Envelopment Analysis (DEA), the study found that police and judicial efficiency must be balanced, since in most cases, if a department has an acceptable police efficiency, it has a bad judicial efficiency performance or vice versa. At large, police efficiency had better performance than judicial efficiency in Colombia.
\end{abstract}

Keywords: DEA; crime; efficiency; judicial.

Martínez Duarte, H. \& Rincón Amaya, K. (2021). Police and judicial efficiency in Colombia. Panorama Económico, 29(4), 206223.

Recibido: 5 de agosto de 2020

Aprobado: 15 de enero de 2021

Autor de correspondencia:

Ángel David Ramírez Romero

ad.ramirezr@uniandes.edu.co

Editor: Andrés Escobar E. Universidad de Cartagena-Colombia.

Tipología IBN Publindex:

Artículo Resultado de Investigación

Científica y Tecnológica

Copyright: (C) 2021. Ramírez Romero, A., Martínez Duarte, H. \& Rincón Amaya, K. Este es un artículo de acceso abierto, distribuido bajo los términos de la licencia https://creativecommons.org/licenses/bync-sa/4.0/ la cual permite el uso sin restricciones, distribución y reproducción en cualquier medio, siempre y cuando que el original, el autor y la fuente sean acreditados.

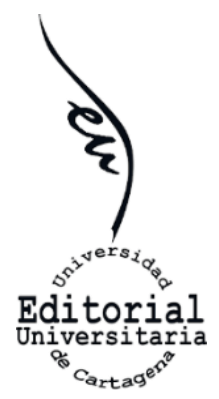

\section{RESUMEN}

Según las teorías socioeconómicas de la conducta delictiva, las tasas de delincuencia pueden reducirse aumentando la probabilidad y la gravedad del castigo. En esta línea, la fuerza pública y el sector judicial juegan un papel importante dependiendo de su desempeño. Este documento analiza este desempeño para cada departamento de Colombia en 2018. Utilizando el Análisis de Envoltura de Datos (DEA), el estudio encontró que la eficiencia policial y judicial debe ser equilibrada, ya que, en la mayoría de los casos, si un departamento tiene una eficiencia policial aceptable, tiene una mala eficiencia judicial o viceversa. En general, la eficiencia policial tuvo un mejor desempeño que la eficiencia judicial.

Palabras clave: DEA; crimen; eficiencia; judicial.

\footnotetext{
1 This research is part from research projects at the University of Pamplona lead by Héctor Daniel Martínez's undergraduate thesis and Jennifer Rincon's research project. Through a joint action with Angel Ramirez, the results of both research projects are presented in this document.
} 


\section{INTRODUCCIÓN}

Security and the fight against crime have become an essential policy for modern states; at the end of the cold war and the ideological conflict, organized crime took relevance within a new economic paradigm (Chabat, 2010). According to Costa (2010), by the end of the 20th century, crime was one of the winners of globalization, opening borders and penetrating state and economic entities. Latin America (LATAM) is known as one of the most dangerous areas on the planet, The Inter-American Development Bank (IDB) displays that LATAM has made progress in poverty, health, and education, but crime seems to be far from being overcome. "One explanation for this is that criminal justice systems do not follow standard measures of effectiveness: homicides solved in the region do not reach 10 \%." (Jaitman, Caprirolo, Keefer, Leggett, Lewis and Torres, 2017, p. 1).

Particularly, in Colombia, urban violence and crime have been linked to its violent past of civil wars and fight against narcotraffic; however, Colombia's problems were caused more by a weak state than by drugs (Holmes and Gutierrez, 2014). Colombia has experienced over a century of sustained increases in GDP per-capita, large increases in educational attainment, rapid urbanization, indeed all the features of modernization. Yet the state has not established a monopoly of violence (Robinson and Urrutia, 2007). In this context, it is not surprising that the bigger worrying of people nowadays is the crime or at least occupies most of the media's discourse. "The concern about this phenomenon is well justified, given its pernicious effects on economic activity and the quality of life of people which must be sustained with a reduced sense of individual security and property." (Fajnzylber, Lederman, and Loayza, 2001, p.4). The armed conflict in Colombia brought about changes in the strategies of the public force and the operations of the illegal armed groups. Based on Ávila (2019), an example of this was the "command" strategy, which consisted of the conjugation of intelligence and operation of the Army, Navy, Air Force, and the Police. After peace agreements in the 21st century with paramilitaries and FARC, the speech turned around the fight against crime rather than internal conflict.

While agreements made with both illegal groups, recurrent problems came to light, in maintaining security on the territory. On the one hand, after the paramilitary demobilization, seven large structures called "Bacrim" emerged, which modified their modes of operation. (Ariel, 2019, p. 473). On the other hand, to implement the Havana peace agreements, the "enormous challenges such as organized crime, urban and rural insecurity, and above all the rampant corruption of politics, justice, and the police," (Hernández, 2016, p. 23). With this record, the efficiency of the public force and the judicial sector come to play an important role in the fight against crime. "Most studies corroborate the hypothesis that the probability of punishment, and to a lesser degree also the severity of punishment, has a deterrent effect on crime. (Garoupa, 2003, p. 13). Within the framework where crime is understood as a decision, and the offender is conceived as a rational subject that measures risk.

As explained at the beginning, crime produces a reasonably high social cost. Becker (1968) ratifies it, and later, Stigler (1970) and Ehrlich (1973). Based on Becker (1968), criminals are rational agents, and their behavior responds to personal benefit versus risk. As Gaviria (201) states "This perspective, initially controversial, has become commonplace within the economic literature. Becker's model predicts that criminals will expand their activities if the 
certainty or dimension of punishment decreases." (p. 164). This analysis came into account for crime policies in the last half of the 20th century, and authors such as Drake and Simper (2005) and Garoupa (2003, p. 12) argue that the "classical theory, even though suffering from some weak aspects identified, is still the best approach to law enforcement."

This article aims to estimate the two main determinants of crime deterrence: police and judicial efficiency. Based on the work of Drake and Simper (2005), the DEA methodology estimates efficiency, according to these authors, the validity and robustness of these relative efficiency results will depend crucially on the specification of an appropriate set of inputs and outputs (Drake and Simper, 2003, p. 709). Thus, this document uses as input the number of police or police staff by department, as well as the number of crimes reported as outputs will be the detentions. In the judicial part, the paper uses as inputs: the workforce and the detentions. As outputs: the number of prosecutions. As a production in the private company, that of the public sector can be considered as a process in which certain inputs, such as the work of officials and physical capital, are combined to obtain specific outputs that can be approximated from indicators such as the crime rate, among others (Garcia and Rosales, 2010).

The document analyzes, by each region, the judicial and police efficiency considering that violence is not monolithic, and policy interventions will have to be adapted to local circumstances (Jaitman et al. 2017). Investigating the optimality of these sectors contributes to a wide range of studies focus on costs and determinants of crime; however, it is crucial to deepen efficiency, since public spending on security in LATAM is higher than developed countries and much when it goes to the police. On the other hand, security spending in the Colombian case has increased in recent decades, since it was considered very small compared to national security threats (Holmes and Gutiérrez, 2014). Further, it gives a new contribution and perspectives to the crime studies widely analyzed in the country such as Laverde, Chavarro and Arce (2011); Tamayo and Norza (2017); Gonzales and Posada (2001); Ortega and Ortiz (2014); García (1998); Collazos, Fergusson, La Rota, Mejía, and Ortega (2020); Sanchez and Núñez (2001), M. Rubio (1995) and Echeverry (1998) among others.

Finally, the document is divided into five sections, starting with this introduction, moving on to the methodology, the results, the discussion, and the conclusions.

\section{LITERATURE REVIEW}

Traditionally, the study of criminal behavior was aimed at psychological or sociological disciplines. However, from the pioneering contributions of Becker (1968) and Ehrlich (1973), economic analysis in areas of human behavior has taken a step to a new approach whose objective is aimed at a better understanding of criminal activity and the different strategies for its control. Hence, the economic theory of crime examines illicit behaviors in terms of a rational choice process by which economic agents assess the expected benefits and costs of alternative courses of action according to a given utility function. On the other hand, there are two types of policies in order to control the level of crime: social prevention policies, which are related to economic conditions, alter the opportunity costs of crime, favoring the actions of agents within the legality, and the dissuasive policies that 
linked to the institutions that make up the criminal justice system, modify the direct costs of crime.

The empirical literature has tried to contrast the influence of one and other factors on crime by including dissuasive variables and variables related to the economic and social environment. The range of notable institutions and agents within criminal justice comprises the police, prosecutors, the prison service, citizens, and the media, as they have a wealth of discretionary powers. Alvesalo (2013) suggests that broad social understandings and institutions constructions and practices should be within the study of criminal justice:

We have to take on board not only the interaction of the decisions and politics of the different agencies involved, but also the shifts of meaning and effect, which are produced by the discourses and practices which subsist within and beyond the obvious contours of the criminal process, and which cut across the obvious institutional division which mark that process. (p. 12)

The United Nations (2010) maintains that the police are the most crucial component of the criminal justice system and that respected police service is a fundamental condition for the positive perception of justice. In the same way, the police are expected to contribute to reducing real problems and levels of subjective insecurity caused by crime and violence in and around cities. As Mohor (2007) mentions, under the police theme, it is essential to permanently incorporate police performance measurement systems that allow monitoring of it and the fulfillment of its objectives.

According to Grabosky (1988), the measurement of police performance should be taken with great caution since the tendency to use crime statistics as a measure of effectiveness is usually one of the classic pitfalls of police performance. For a long time, the response time has been assumed as one of the indications of police effectiveness. This mode refers to the higher the probability of capturing the person who committed the crime if the police officers arrive at the crime scene earlier. However, not all crimes are susceptible to the impact of timely police response, since many victims do not immediately notify the police when they discover that a crime has been committed. According to Grabosky (1988):

\footnotetext{
The keys to efficiency in police action are improvements in management, access to more opportune costs and information on expenses, continuing with the decentralization of the police administration, and the requirement that all requests for additional resources be accompanied by detailed justification (p. 6).
}

Thus, as mentioned, Weisburd (2008), the efficiency of police strategies can be defined in different ways, depending on the characteristics of the police that you want to maximize; therefore, efficiency is essential in police surveillance because Police resources are limited. On the other hand, an essential component of a "good" justice system is its efficiency, studies on the importance of judicial efficiency have found strong positive correlations between it and business performance (Lepore et al, 2017) reliability of the legal system (Ippoliti, Melcarne, and Ramello, 2015) and even therapeutic effects derived from access to efficient justice systems (Schepard and Bozzomo, 2003). In addition, empirical evidence shows that the justice system depends on multiple factors such as the personnel who work 
in the courts as well as the availability of the reinforcement personnel, the educational achievement of the judges and the time that the judges dedicate to adjudication and administrative tasks. Therefore, the analysis of productive efficiency allows to evaluate whether the production factors of each judicial body are being used properly, so that the technical efficiency is reflected (the courts are producing the maximum number of decisions, given a particular combination of factors), or if there is allocative efficiency (courts produce justice at the lowest possible cost) despite the fact that historically the private sector has been intrinsically linked to the effectiveness of the justice system.

Recently, the increase in public spending in different countries has given way to the need to evaluate and promote the efficient use of resources in various areas of the public sector. However, Pastor (1993), Buscaglia and Ulen (1997) and Rosales (2008) affirm that the increase in public spending has a positive effect on the supply of justice. Still, if it is observed in the medium term, it does that the demand for justice increases, intensifying judicial saturation, which as a result, makes it difficult to know its net effect on efficiency.

\section{METHODOLOGY}

Data Envelopment Analysis (DEA) is introduced by Charnes, Cooper, and Rhodes (1978), also is considered as an extension of Farrell (1957) pioneering work on measuring technical efficiency. DEA is an empirical methodology approach to evaluate the performance of entities sets called: Decision Making Units (DMUs). These units convert a handful of inputs into multiple outputs using a mathematical programming technique that allows the construction of an empirical production function from the available data. In this way, the units that determine the production function are called Efficient Units. Any DMU achieves full efficiency if and only if none of its inputs or outputs can improve without worsening some of its other inputs or outputs. Those that do not remain on it are called inefficient Units. The DEA methodology allows the evaluation of the relative efficiency of each of the units. According to Farrel (1957), efficiency is conceived as the optimal relationship between used elements and achieved output. Thus, the value of the efficiency of a unit it is expresses as:

$$
\text { Efficiency }_{i}=\frac{\text { output }_{i}}{\text { Input }_{i}}
$$

Where the analyzed unit's efficiency is going to be inversely determined by the magnitude of the input necessary for the production level, however, in cases where there is more than one input interaction, the relationship is more complicated. To determine the best performance between two DMUs in (1) is necessary to establish the derivation based on the broadest quotient; however, when it comes to cases where more factors are involved in the process, the analysis proceeds as follows:

$$
\text { Efficiency }=\frac{\text { the sum of the outputs' weight } * \text { output's magnitude }}{\text { the sum of the inputs' weight } * \text { input's magnitude }}
$$

Where efficiency is understood for Unit j as:

$$
E_{j}=\frac{U_{1} Y_{1 j}+U_{2} Y_{2 j}+\cdots+U_{n} Y_{n j}}{V_{1} X_{1 j}+V_{2} X_{2 j}+\cdots+V_{n} X_{n j}}
$$

Where: 
$\mathrm{U} 1=$ Weighting given at output 1

Y1j = Quantity of output 1 for unit $j$

$\mathrm{V} 1=$ Weighting given to input 1

$X 1 j=$ Quantity of input 1 for unit $j$

Nevertheless, as the number of inputs and DMU levels increase, a simple analysis can be a tedious way to determine the degree of the variables' efficiency; thus, Farrell, (1957) enlargement of work provides a straightforward and more methodologically appealing way.

Data on crime captures, and judicial processes of each section per period were obtained by looking at the Statistical System of the Crime Observatory of the National Police and the Oral Accusatory Criminal System (SPOA in Spanish) of the Attorney General's Office of the Nation (Fiscalía General de la Nación). Therefore, Figure 1 summarizes the data.

Table 1. Input and Output variables

\begin{tabular}{ccc}
\hline Variable & Policial Efficiency & Judicial Efficiency \\
\hline $\begin{array}{c}\text { Input } 1 \text { (Not } \\
\text { controlled) }\end{array}$ & The number of crimes & The number of captures \\
Input 2 & The number of active & Number of staff \\
Output & agents & The number of resolved \\
procedures
\end{tabular}

Source: Based on Crime Observatory of the National Police and the Oral Accusatory Criminal System

Then, the specification of the artificially constructed variable under the methodology of Banker and Thrall (1992), it will perform out as follows:

$\operatorname{Min}_{\theta, \lambda, s^{+}, s^{-}} Z_{0}=\varphi+\varepsilon\left(I s^{+}+I s^{-}\right)$

Subject to:

$$
\begin{aligned}
& \lambda \mathrm{Y}=\varphi \gamma_{0}+s^{+} \\
& \lambda \mathrm{X}=\mathrm{x}_{0}-\mathrm{s}^{-} \\
& \overline{1} \lambda=1
\end{aligned}
$$

Where $1 / \varphi^{*}$ represents the efficiency only when $\varphi^{*}=1$ and the width is null.

Therefore, the relative efficiency of the evaluated system (whether judicial or police) will depend on the minimization problem's resolution under the simplex method, where each evaluated administrative department makes a result. It needs clarifying that, efficiency will oscillate ranging zero and one, where values close to one represent higher performances and vice versa. Hence, the implementation of this method to the model estimated provides a simplification by corresponding to the analysis of the public deterrence system 
and additionally makes the mathematical rigor of the model more robust for academic purposes.

\section{RESULTS}

Detentions made in 2018 in the country's departments averaged 1,980; on the other hand, 95\% of the departments concentrate between 0 and 7,240 detentions. Regarding the police staffing, the number of police officers per department is, on average, 21,220 with a margin of error of $13.9 \%$, which indicates signs of uneven concentration. Concerning the above, the value of crimes in the country is 12,700 cases, the equivalent of 1.6 police officers for each crime committed on average. However, crime presents a somewhat unequal distribution in 95\% of the observations; crimes range from approximately 5,300 cases to around 20,000.

The cases processed along the territory in 2018 averaged 870 cases, these variables present an equal distribution between the departments and a margin of error of less than $10 \%$. Thus, $43.7 \%$ of the detentions are effectively prosecuted, which indicates that only 9 out of 20 cases are fully prosecuted. As for the operational personnel of the judicial sector, there are 719 active agents in 2018 in each of the country's departments, in comparison, there are 29 policies for each agent of the judicial operational sector.

Table 2. Descriptive Statistics

\begin{tabular}{cccccc}
\hline & Detentions & Police officers & Crimes & Judicializations & Personnel \\
\hline Media & $1.988,70$ & $21.220,76$ & $12.703,18$ & 873,67 & 719,61 \\
Typical error & 536,58 & $6.189,12$ & $3.758,28$ & 168,22 & 209,87 \\
Median & $1.206,00$ & $11.441,00$ & $5.948,00$ & 512,00 & 388,00 \\
Standard Desviation & $3.082,39$ & $35.553,76$ & $21.589,67$ & 966,33 & $1.205,63$ \\
Sample Variance & $9.501 .158,59$ & $1.264 .069 .956,25$ & $466.113 .703,84$ & $933.801,10$ & $1.453 .550,93$ \\
Kurtosis & 18,78 & 13,53 & 9,86 & 4,36 & 13,53 \\
Sample variance & 3,99 & 3,47 & 3,03 & 1,97 & 3,47 \\
Range & $17.087,00$ & $181.074,00$ & $103.086,00$ & $4.279,00$ & $6.140,00$ \\
Minimum & 20,00 & 375,00 & 79,00 & 31,00 & 13,00 \\
Maximum & $17.107,00$ & $181.449,00$ & $103.165,00$ & $4.310,00$ & $6.153,00$ \\
Observations & 33,00 & 33,00 & 33,00 & 33,00 & 33,00 \\
Confidence level (95.0\%) & $1.092,97$ & $12.606,82$ & $7.655,36$ & 342,65 & 427,50 \\
\hline
\end{tabular}

Source: Criminal and operational statistics. Observatorio del delito de la policía nacional. ODPN.

Figure 1 displays that many resources do not always determine efficiency. Departments such as the Guaviare, the Guajira and Vaupés, despite having limitations in terms of police resources, present satisfactory and outstanding results at the country level. On the other hand, departments with more resources such as Nariño, Santander, and Bogotá also have efficient scores. With respect to inefficient departments, Huila stands out. With poor police management compared to other departments, should have obtained 3,257.9\% more detentions than those registered in 2018. Likewise, within the worst-result departments, Guainía needs to increase its detentions by $454.7 \%$ with a police force $11.8 \%$ lower to become efficient. Amazonas requires a reduction of the police personnel by $29.9 \%$ and 
with this endowment it is necessary to increase the captures (given the level of crime) to become efficient.

Efficiency's degree can be identified according to the color scale (figure 1). More color represents a higher police efficiency score; the scores are divided into three groups consisting of LOW, MEDIUM, and HIGH (with cumulative ranges of $1 / 3$ respectively). Thus, most of the departments with low scores are in the South-Eastern part of Colombia, specifically in the border area, the average efficiency police is $24.3 \%$. With respect to the departments with a "Medium" score, this condition occurs in $42.8 \%$ of the departments of the Caribbean region and $50 \%$ of the departments belonging to the Pacific region. Hence, they represent approximately one of every three departments in the country; 90.9\% of the departments in this condition are in the central and northern part.

Figure 1. Police Efficiency

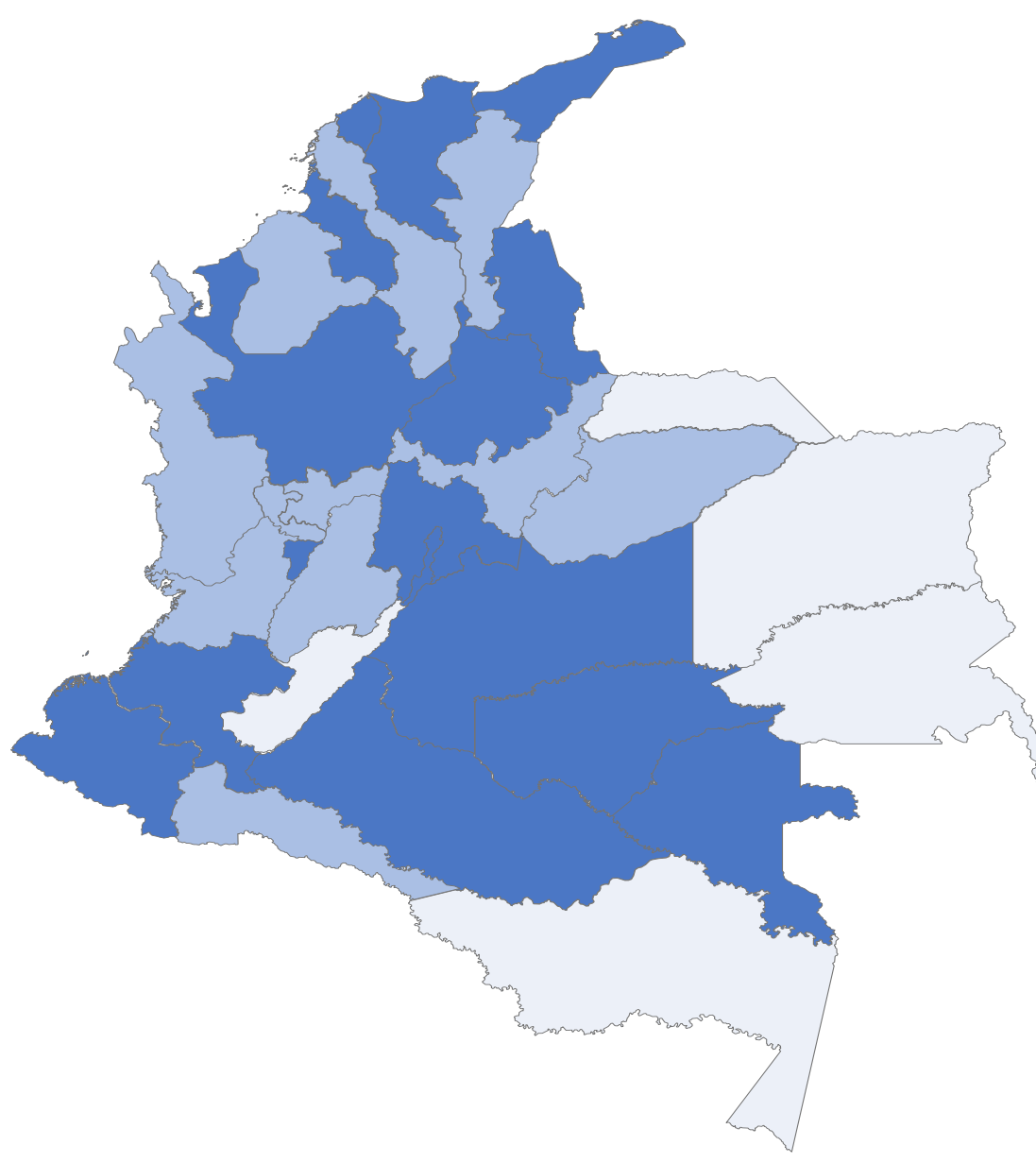

Source: Criminal and operational statistics. Observatorio del delito de la Policía Nacional. ODPM.

By calculating the stochastic output distance frontier (SODF), 36.36\% of the DMU that have low levels of efficiency, the potential improvement is more significant than $40 \%$, which indicates that their standards are below acceptable levels. Moreover, statistical inference displays that, in 95\% of the cases, it represents a maximum of $54.5 \%$ of the departments (and failing that the municipalities that compose it) and $33.3 \%$ at least. In 
other words, the empirical evidence glimpses that the performance of the departments requires an improvement between 33.3\% and 54.5\% of the current production of country's departments.

Table 3. Results

\begin{tabular}{|c|c|c|c|}
\hline Unit name & SODF & SODF Minimum & SODF Maximum \\
\hline Vaupés & 0 & -13.5587165 & 0 \\
\hline Guaviare & 0 & -13.5587165 & 0 \\
\hline La Guajira & 0 & -13.5587165 & 0 \\
\hline Nariño & 0 & -13.5587165 & 0 \\
\hline Santander & 0 & -13.5587165 & 0 \\
\hline Bogotá & 0 & -13.5587165 & 0 \\
\hline Meta & -15.23 & -26.723724 & -3.73627599 \\
\hline Norte de Santander & -21.87 & -32.4634252 & -11.2765748 \\
\hline Cauca & -22.16 & -32.714105 & -11.605895 \\
\hline Quindío & -25.84 & -35.8951442 & -15.7848558 \\
\hline Cundinamarca & -28.16 & -37.900582 & -18.419418 \\
\hline Caquetá & -28.85 & -38.4970268 & -19.2029732 \\
\hline Magdalena & -28.89 & -38.5316033 & -19.2483967 \\
\hline Atlántico & -30.03 & -39.517034 & -20.542966 \\
\hline Sucre & -30.41 & -39.8455108 & -20.9744892 \\
\hline Antioquia & -30.67 & -40.0702582 & -21.2697418 \\
\hline Risaralda & -36.53 & -45.1357174 & -27.9242826 \\
\hline Cesar & -37.33 & -45.8272477 & -28.8327523 \\
\hline Caldas & -38.59 & -46.9164078 & -30.2635922 \\
\hline Tolima & -38.79 & -47.0892904 & -30.4907096 \\
\hline Valle del Cauca & -38.94 & -47.2189523 & -30.6610477 \\
\hline Boyacá & -43.72 & -51.3508457 & -36.0891543 \\
\hline Bolivar & -48.53 & -55.5086714 & -41.5513286 \\
\hline Córdoba & -51.58 & -58.1451305 & -45.0148695 \\
\hline Casanare & -55.23 & -61.3002374 & -49.1597626 \\
\hline Putumayo & -62.61 & -67.6796041 & -57.5403959 \\
\hline Chocó & -63.51 & -68.4575757 & -58.5624243 \\
\hline Vichada & -69.13 & -73.3155758 & -64.9444242 \\
\hline Arauca & -72.81 & -76.496615 & -69.123385 \\
\hline San Andrés & -76.6 & -79.7727397 & -73.4272603 \\
\hline Amazonas & -78.43 & -81.3546152 & -75.5053848 \\
\hline Guainía & -81.97 & -84.4146366 & -79.5253634 \\
\hline Huila & -97.02 & -97.4240498 & -96.6159502 \\
\hline
\end{tabular}

Source: Criminal and operational statistics. Observatorio del delito de la policía nacional. ODPM.

Figure 2 shows the percentage dispersion between departments and show a relatively consistent behavior in the case of crimes and the number of active police. Improvements are needed but not in most cases; for Cundinamarca, there is a fairly marked criminal offer, which indicates that this criminal oversupply must be balanced with a more significant number of agents improving the department's situation. The increase mentioned above is between 7,696 and 32,867 agents, the above with a 95\% confidence level. 
Figure 2. Police Officers and detentions

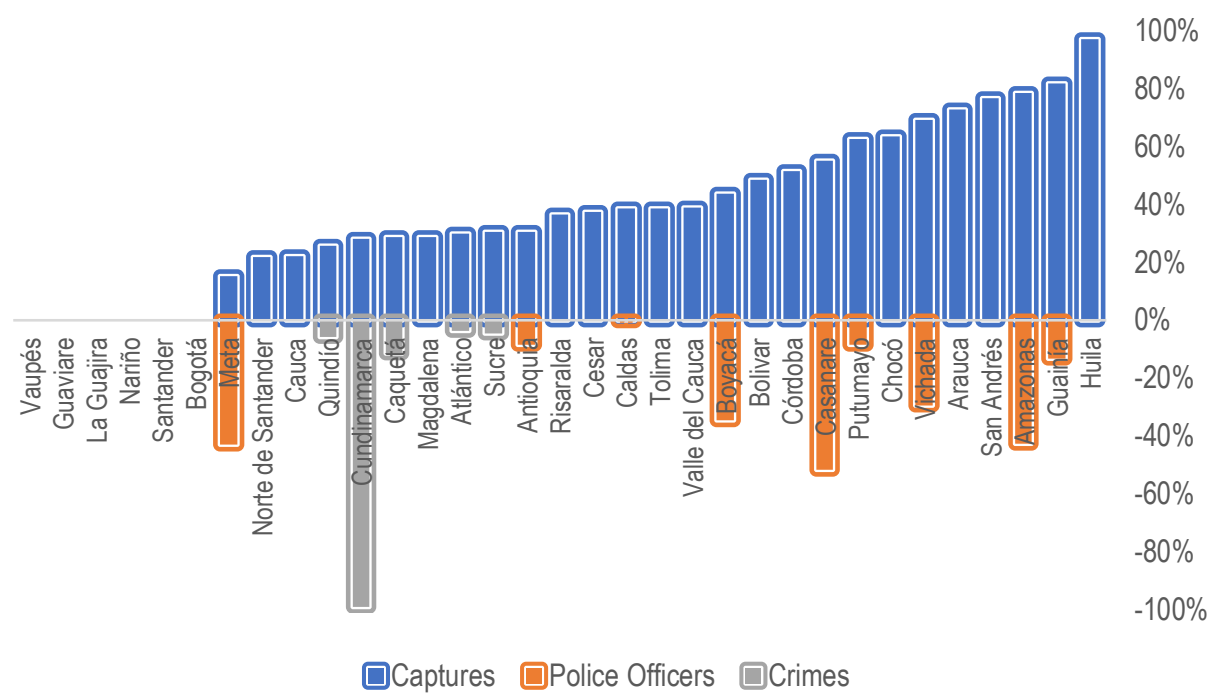

Source: Criminal and operational statistics. Observatorio del delito de la policía nacional. ODPM.

As can be identified, in terms of detentions, in most of cases, efficiency is due to transformation issues because, with the necessary inputs, they do not obtain the expected results. This situation translates into two positions, low technical efficiency and low productivity; therefore, for the resolution of these factors that harm the general performance of the police institutions, it is necessary to promote technological progress to improve the results obtained. The distribution of the scores regarding the judicial aspect seems to be uniform at each of the levels. Compared to the results obtained by the operative part, which suggests that there is heterogeneity in the distribution of judicial efficiency in the country, where the scores obtained by the departments evaluated are more evenly distributed in each of the ranges. Given the above, $24.24 \%$ of the administrative departments evaluated have high scores; this is 1.6 times higher than the percentage of departments with high police efficiency, which shows that organizational efficiency, as a preliminary, is 1.6 times better than the operative.

The departments with full efficiency are Bogotá, Caquetá, Huila, Norte of Santander, Valle del Cauca, and Vaupés, where it is stated that the administrative results to carry out the process of judicialization of those responsible for criminal acts is optimal. Further, results identify that only 2 of the departments with police efficiency are also efficient concerning the adjudication's process and conviction for criminal acts, this relationship reveals that having an excellent performance in the Capturing the cases does not imply good results in the prosecution and the departments' improvement plan must contemplate these two situations for full efficiency in the country.

Figure 3 adds units that have low and high efficiency. The case of La Guajira stands out, which has the worst management compared to the other departments of the country. Given its level of physical resources (human capital destined for the judicialization of criminals in the department) and their number of arrests, La Guajira obtained in 2018 less than 900 prosecutions of those expected. This regards that achieve efficiency required improving their performance by $914.2 \%$ all the above with $21.4 \%$ fewer agents today. 
Most of the departments with low scores are in the Northeast part of the country, specifically on the Caribbean coast. The average judicial efficiency of these departments is $25.4 \%$, which is $3.8 \%$ higher than the average efficiency of the police sector; Moreover, as for the departments with a "Medium" score, this condition occurs in $46.0 \%$ of the country's departments, $2.3 \%$ less than police efficiency. Also, it corresponds to 4 out of 10 departments in the country, but mainly concentrated in the Pacific region, where it represents $75 \%$ of the departments in that region. Finally, close to $74 \%(73.9 \%)$ of the departments with major cities in the country have a "High" efficiency.

Figure 3. Judicial efficiency

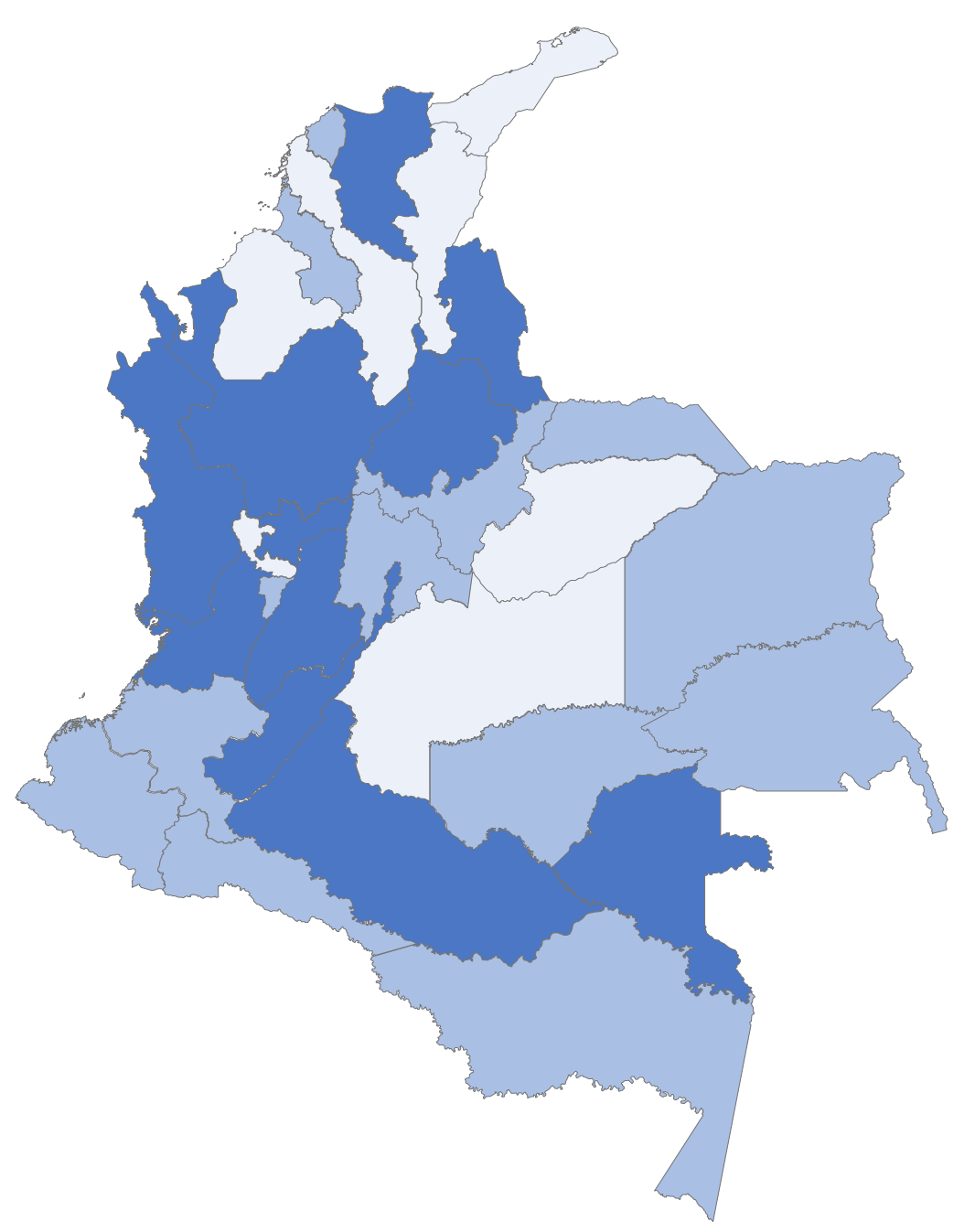

Source: Criminal and operational statistics. Observatorio del delito de la policía nacional. ODPM.

By calculating the SODF for judicial efficiency, it was possible to identify that $63.63 \%$ of the analyzed departments have low levels of efficiency; also, the potential improvement is more significant on $40 \%$, indicating that 1.75 more departments are below than acceptable performances in the judicial aspect. Thus, the judicial sector in the country requires necessary improvements to increase performance. This need is more markedly here than in the police sector. Statistical inference yields that, 95\% of the cases, this number may represent a maximum of 7 out of 10 (69.69\%) departments in the country, 
and a minimum of $60.60 \%$, which means that the judicial efficiency should improve between $60 \%$ and $70 \%$. Guaviare presents an excess of detentions (figure 4), which are the main factor that limits efficiency, therefore, to mitigate the impacts from this effect, it is possible to resort to the expansion of personnel to cover more extensively the number of captures or to carry out processes improving the productivity of active staff which guarantees a higher processing rate.

Figure 4. Courts and Detentions

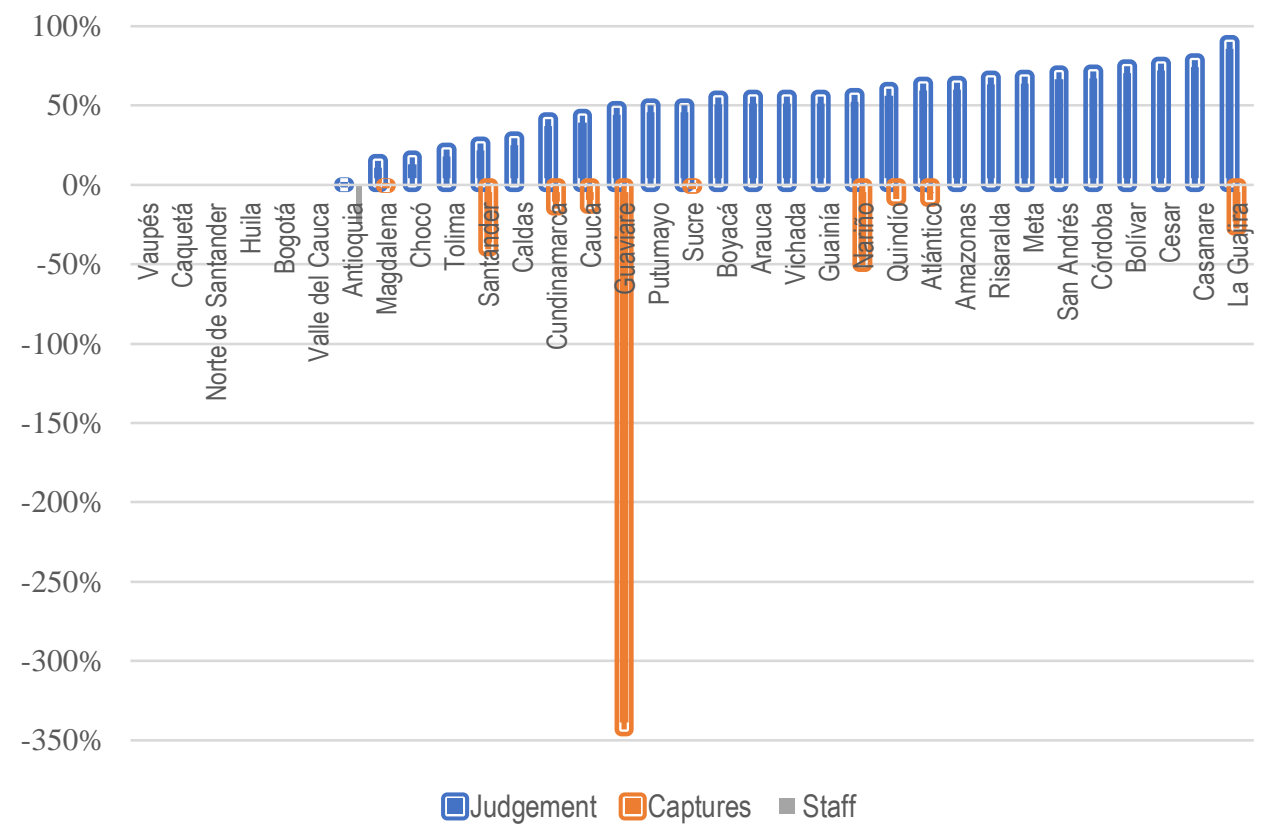

Source: criminal and operational statistics. Observatorio del delito de la policía nacional. ODPM. Made by the authors.

This analysis could identify that in most of the departments, results can be improved based on the inputs obtained, which represents that departments' general productivity analyzed is relatively low. Rather than making reductions in staff, entities must articulate the two aspects, and particularly improve their productivity to absorb the excess inputs evidenced.

That is, minimize excess productivity through productivity complaints that exist in the operational sector (police) and excess detentions in the administrative (judicial).

Table 4. Results

\begin{tabular}{lccc}
\hline Unit name & SODF & SODF Minimum & SODF Maximum \\
\hline Vaupés & 0 & -15.8976863 & 0 \\
Caquetá & 0 & -15.8976863 & 0 \\
Norte de Santander & 0 & -15.8976863 & 0 \\
Huila & 0 & -15.8976863 & 0 \\
Bogotá & 0 & -15.8976863 & 0 \\
Valle del Cauca & 0 & -15.8976863 & 0 \\
Antioquia & -0.54 & -16.3518388 & 0 \\
Magdalena & -14.9 & -28.428931 & -1.37106895
\end{tabular}




\begin{tabular}{|c|c|c|c|}
\hline Chocó & -17.27 & -30.4221559 & -4.11784412 \\
\hline Tolima & -22.14 & -34.5179386 & -9.76206144 \\
\hline Santander & -25.96 & -37.7306469 & -14.1893531 \\
\hline Caldas & -29.51 & -40.7162791 & -18.3037209 \\
\hline Cundinamarca & -41.57 & -50.8590181 & -32.2809819 \\
\hline Cauca & -43.54 & -52.5158337 & -34.5641663 \\
\hline Guaviare & -48.72 & -56.8723335 & -40.5676665 \\
\hline Putumayo & -50.04 & -57.9824841 & -42.0975159 \\
\hline Sucre & -50.21 & -58.125458 & -42.294542 \\
\hline Boyacá & -55.1 & -62.2380612 & -47.9619388 \\
\hline Arauca & -55.52 & -62.5912909 & -48.4487091 \\
\hline Vichada & -55.73 & -62.7679057 & -48.6920943 \\
\hline Guainía & -55.88 & -62.8940592 & -48.8659408 \\
\hline Nariño & -56.77 & -63.6425698 & -49.8974302 \\
\hline Quindío & -60.71 & -66.956201 & -54.463799 \\
\hline Atlántico & -63.74 & -69.5045011 & -57.9754989 \\
\hline Amazonas & -64.45 & -70.1016275 & -58.7983725 \\
\hline Risaralda & -67.65 & -72.7929015 & -62.5070985 \\
\hline Meta & -68.38 & -73.4068484 & -63.3531516 \\
\hline San Andrés & -71.1 & -75.6944313 & -66.5055687 \\
\hline Córdoba & -71.27 & -75.8374053 & -66.7025947 \\
\hline Bolívar & -74.78 & -78.7893965 & -70.7706035 \\
\hline Cesar & -76.36 & -80.118213 & -72.601787 \\
\hline Casanare & -78.4 & -81.8339002 & -74.9660998 \\
\hline La Guajira & -90.14 & -91.7075119 & -88.5724881 \\
\hline
\end{tabular}

Source: Criminal and operational statistics. Observatorio del delito de la policía nacional. ODPM.

By analyzing the behavior of the calculated efficiencies, it was initially possible to identify that, in the police aspect, only six of the Departments evaluated have relevant conditions to be efficient. Further, the police force and the number of crimes were consistent with the detentions that occurred in the administrative departments analyzed. On the other hand, about 15.15\% had a high level of efficiency, a value 2.8 and 1.6 times less than the proportion of Departments with medium and low efficiency $(42.4 \%$ and $24.3 \%$ respectively).

Finally, the global efficiency (defined as the average between the efficiencies of the two sectors analyzed), yields that the efficiency at a general level is concentrated between $20 \%$ and $100 \%$ of the score, which means that the main concentration of global efficiency in the country is above the first quintile.

The above implies that the system large must make a maximum adjustment in the results of $80 \%$ to achieve full technical efficiency in mitigating the costs and effects of crime in the country. Likewise, $57.57 \%$ of the departments analyzed must make significant improvements to achieve efficiency since they are below acceptable levels of productivity. This value is $10.5 \%$ less than in the judicial-sector case and $6.17 \%$ less than in the police efficiency case. 
Figure 5.

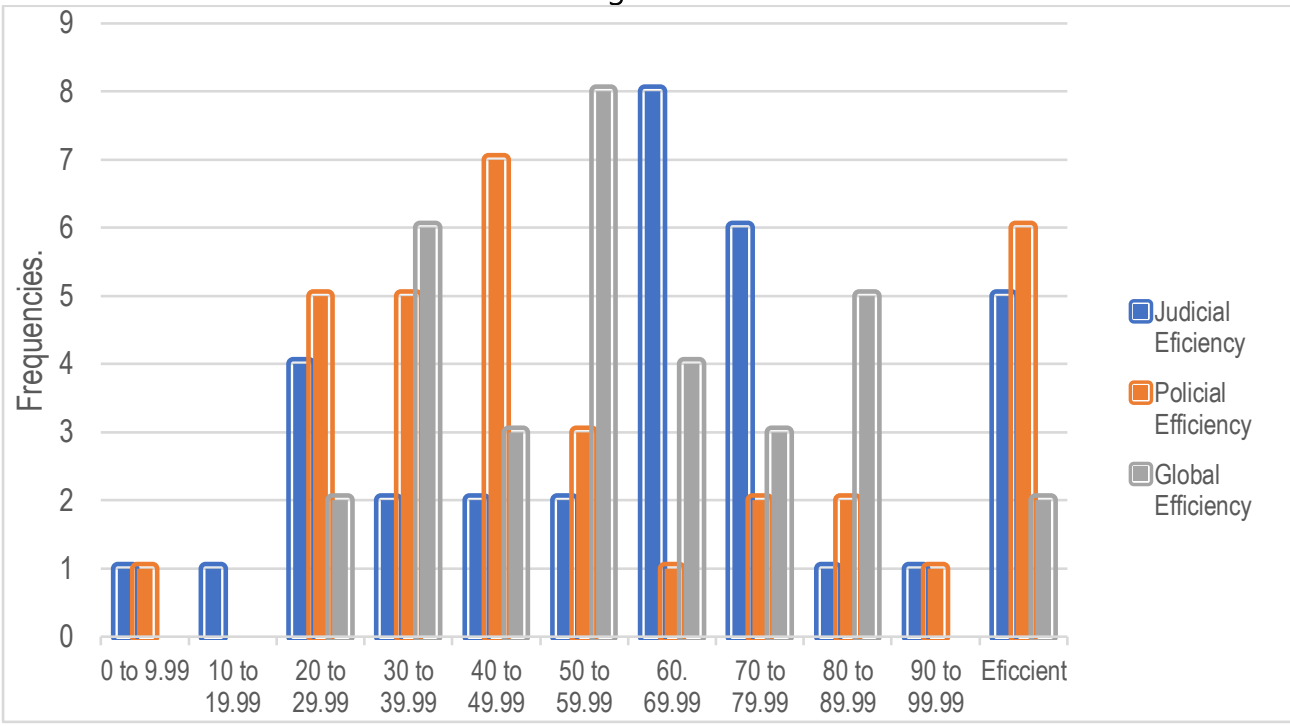

Source: criminal and operational statistics. Observatorio del delito de la policía nacional. ODPM. Made by the authors.

\section{DISCUSSION}

In economics, there has been always an interested on illegal behavior. From Smith through Petty to Jeremy Bentham, raised questions such as security spending and its origin, the optimal number of agents against crime, the severity of sentences (Erlich, 1996). In those latitudes, the demand for protection against crime was motivated by the concentration of final goods. Therefore, crime is highly related to economic growth until today, and economic models conceive criminals as individuals who move to through incentives. In the Colombian case, the analysis is more complex, as shown by Gaviria (2001). For this country, several trends needed to tackle crime. Among them, the neoclassical proposed by Becker (1968) stands out, as well as the objective causes that explain the violence as the result of poverty, exclusion, the lack of state presence, the scarce provision of social services and income inequality (Torres and Núñez, 2001).

For this research, the neoclassical line was chosen due to the variables studied; moreover, according to Rubio (2000), it is not recommended to think of violence as an act generated by individuals pressured by their unmet needs because of high crime rates appear in cities with more education and employment. In last years, despite progress in reducing violence in Colombia, crime in cities stayed high. Also, in some cases, there are increasing trends over time (Mejía, Ortega and Ortiz, 2015). Additionally, modern cities compared to other areas of the country continue to present high rates in the different types of crime.

It is important to clarify that the information available is accusations. Thus, the culture of the report may be more present in urbanized areas, giving an ambiguous signal of crime throughout the territory, since many variables must be considered. Thus, Ostrom (1972) argues that the police is one of the most important factors of security in a community, but it is not alone. Penal system, labor market, educational system, housing market, court system, and welfare system have consequences in community's security. In most cases, these systems have more influence on security than the police itself. 
According to the results obtained for the Colombian case, "among many tools that can be used to intervene against crime, the Police is undoubtedly a central actor" (Tamayo and Norza, 2018, p. 52). Police efficiency is higher than that of the judicial sector, and a more uneven weight in the territory presents more encouraging results. Bogotá and Vaupés achieved absolute efficiencies with different resources, which is essential for the analysis of productivity; that is, efficiency is not affected by this relationship with the increase in staff and support, but in the productivity of the state concerning the level of crime in each territory. The above in a different direction to the study by Chalfin and McCarary (2013), where they display that a more significant investment in the police forces leads to a decrease in crime in the USA's cities.

On the other hand, the role of the public force cannot be omitted; its changes in strategies have important consequences. Moreover, in two years the National Police seems to have doubled its capacity to register Colombian rate crimes (Tamayo and Norza, 2018). However, for 2017, the regions that most need to improve are the Amazon and Orinoquía. In contrast, the departments with the highest number of detentions were Antioquia, Bogotá DC, Santander, Valle, and Cundinamarca, where 45.170, 38.148, 16.794 were registered, 16.601 and 12.422, respectively. The concentration of the detentions in Antioquia, Bogotá, Valle, and Cundinamarca is not surprising, since they are the departments with the most significant number of inhabitants. Nevertheless, the presence of the "Santander department attracts attention, since Atlántico and Bolívar have a larger population" (Tamayo and Norza, 2018, p. 67).

Regarding judicial efficiency, despite being more homogeneous along the territory, in general, it had lower results. This trend has been improving very slowly since the beginning of the 21st century. According to Gonzales and Posada (2001): "the main problems of the judicial system in Colombia were the high degree of congestion, slowness, and impunity" (p. 90). Additionally, Collazos et al (2020) show that Colombia is an ideal case study, given the poor performance of homicide investigations in the country with meager rates of charges and charges solved.

\section{CONCLUSION}

Efficiency has traditionally been related more to the private than the public sector. However, the increase in spending in various countries and the renewal of results-oriented public administration has raised the need to measure and promote the efficient use of public resources (Gracia and Rosales, 2010). The increase in public spending in some countries such as those in Latin America and the Caribbean has led to an increase interest on public policies for crime reduction given the higher crime rates in this region. In addition, from another perspective, they represent a considerable opportunity cost.

In the Colombian case, public policies are oriented towards increasing the number of police officers and investing in technology to lower crime rates. However, complaints are recurrently aimed at the effectiveness and corruption of the judicial sector. This document proposes that both the police and judicial system need to be balanced to perform better. Results show that many departments present high police efficiency and low judicial efficiency. In other cases, happens the opposite, which indicates that both sectors need to overcome productivity barriers, and increase coordination. 
Consequently, the study found that efficiency is uneven throughout the Colombian territory. Regarding the global efficiency of both sectors, Colombia presents an acceptable performance but far from excellence. Thus, these results can contribute to the policy agenda in terms of productivity and efficiency of institutions to reduce crime rates.

\section{REFERENCES}

Chabat, J. (2010). El Estado y el crimen organizado trasnacional. En: Revista de Historia Internacional. Doi: http://www.istor.cide.edu/archivos/num 42/dossier1.pdf

Costa, A. M. (2010). The economics of crime: A discipline to be invented and a Nobel Prize to be awarded. Journal of Policy Modeling, 32(5), 648-661.

Jaitman, L., Caprirolo, D., Ochoa, R. G., Keefer, P., Leggett, T., Lewis, J. A., ... \& Torre, I. (2017). Los costos del crimen y de la violencia: nueva evidencia y hallazgos en América Latina y el Caribe. Monografía del BID: New York. http://dx.doi.org/10.18235/0000615

Holmes, J. S., \& Amin Gutiérrez de Piñeres, S. (2014). Violence and the state: Lessons from Colombia. Small Wars \& Insurgencies, 25(2), 372-403.

Fajnzylber, P., Lederman, D., \& Loayza, N. (2001). CRIMEN Y VICTIMIZACION: UNA PERSPECTIVA ECONOMICA. En P. Fajnzylber, D. Lederman, \& N. Loayza, Crimen y Violencia en América Latina (págs. 1-63). Bogotá, D.C.: Alfomega S.A.

Ávila, A. (2019). Detrás de la guerra en Colombia. Bogotá: Editorial Planeta Colombiana, SA, 529 p.

Hernández, C. L. (2016). ¡Adiós a las Farc! ¿Y ahora qué? Bogotá D.C: Debate, 438 p.

Garoupa, N. (2003). Behavioral economic analysis of crime: A critical review. European Journal of Law and Economics, 15(1), 5-15.

Ehrlich, I. (1996). Crime, Punishment, and the Market for Offenses. In: Journal of economic perspectives, 43-67. Doi: https://www.aeaweb.org/articles?id=10.1257/jep.10.1.43

García Rubio, M. A., \& Rosales, V. (2010). Justice \& economy: Evaluating judicial efficiency in Andalusia. InDret, 4. Doi: https://papers.ssrn.com/sol3/papers.cfm?abstract id=1738227

Becker, G. (1968). Crimen y castigo: un enfoque económico. En: Microeconomía, 272-297. Doi: http://ebour.com.ar/ensayos meyde2/Gary\%205.\%20Becker\%20\%20Crimen\%20y\%20Castigo. pdf

Gaviria, A. (2001). Rendimientos crecientes y la evolución del crimen violento: el caso colombiano. En A. Martínez Ortiz, Economía, crimen y conflicto. (pág. 431). Bogotá: Ediciones Antropos Ltda. Doi: http://www.scielo.org.co/scielo.php?script=sci arttext\&pid=s0121-47722001000100009

Drake, L. M., \& Simper, R. (2005). Police efficiency in offences cleared: An analysis of English "Basic command units". International Review of Law and Economics, 25(2), 186-208.

Chalfin, A., \& McCrary, J. (2013). The effect of police on crime: New evidence from US cities, 1960 2010 (No. w18815). National Bureau of Economic Research. Doi: https://www.nber.org/papers/w18815.pdf

Drake, L. M., \& Simper, R. (2003). An evaluation in the choice of inputs and outputs in the efficiency measurement of police forces. The Journal of Socioeconomics, 32(6), 701-710.

Ostrom, E. (1973). On the meaning and measurement of output and efficiency in the provision of urban police services. Journal of Criminal Justice, 1(2), 93-111. 
García, G. S. (1998). La policía en Colombia: paradojas de un modelo policial en una sociedad conflictiva. Revista catalana de seguretat pública, 137-178.

Robinson, James A. y Miguel Urrutia eds. (2007) Economía Colombiana del Siglo XX: Un Análisis Cuantitativo, Bogotá y México D.F.: Fondo de Cultura Económica

González, F., \& Posada, C. E. (2001). Criminalidad, violencia y gasto público en defensa, justicia y seguridad en Colombia. Revista de economía institucional, 3(4), 78-102.

González, F., \& Posada, C. E. (2001). Criminalidad, violencia y gasto público en defensa, justicia y seguridad en Colombia. Revista de economía institucional, 3(4), 78-102. Doi: https://www.redalyc.org/pdf/419/41900405.pdf

Collazos, D., Fergusson, L., La Rota, M., Mejía, D., \& Ortega, D. (2020). CSI in the Tropics Experimental Evidence of Improved Public Service Delivery Through Coordination. Documento CEDE, (20). Doi: https://papers.ssrn.com/sol3/papers.cfm?abstract id=3629933

Grautoff Laverde, M., Chavarro Miranda, F., \& Arce, A. F. (2011). La teoría racional del crimen. Aplicaciones de Gary Becker en Bogotá, DC. Criterio libre, 9(14), 91-124. Doi: https://biblat.unam.mx/hevila/Criteriolibre/2011/vol9/no14/4.pdf

Tamayo-Arboleda, F. L., \& Norza-Céspedes, E. (2018). Midiendo el crimen: cifras de criminalidad y operatividad policial en Colombia, año 2017. Revista Criminalidad, 60(3), 73-93. Doi: http://www.scielo.org.co/pdf/crim/v60n3/1794-3108-crim-60-03-00073.pdf

Echeverry, J. \& (1998). Por qué la justicia no responde al crimen: el caso de la cocaína en Colombia. En M. C. Steiner, Corrupción, Crimen y Justicia: Una Perspectiva Económica. Bogotá: Tercer Mundo, $17 \mathrm{p}$.

Sánchez Torres, F., \& Núñez, J. (2001). Determinantes del crimen violento en un país altamente violento: El caso de Colombia. En: Coyuntura Económica, 92-116.

Mauricio, R. (1995). Crimen y Crecimiento en Colombia. En: Coyuntura Económica, 101-125. Doi: https://www.repository.fedesarrollo.org.co/handle/11445/2198

Mauricio, R. (2000). Violencia y conflicto en los noventa. En: Fedesarrollo, 151-186.

García Rubio, Miguel A.; Rosales, Virginia. (2010) Justice \& economy: Evaluating judicial efficiency in Andalusia. InDret, vol. 4.

Buscaglia Y Ulen. (1997). A Quantitative Assessment of Efficiency of the Judicial Sector in Latin America. International Review of Law and Economics.

Cloninger, D.O. (1994). Enforcement risk and deterrence: a re-examination. The Journal of Socioeconomics.

Grabosky P. (1988). Efficiency and effectiveness in Australian policing. Trends \& issues in crime and criminal justice.

Alvesalo, A. (2003). The dynamics of economic crime control. Helsinki: Police College of Finland. Doi:

https://www.researchgate.net/profile/Anne Alvesalo/publication/277940956 The Dynamics of Economic Crime Control/links/5576cc4808aeacff1ffef60d/The-Dynamics-of-Economic-Crimecontrol.pdf

Ippoliti R., Melcarne A., and Ramello G. (2015). Judicial efficiency and entrepreneurs' expectations on the reliability of European legal systems. European Journal of Law and Economics. 
Lepore L., Paolone F., Pisano S. y Alvino F. (2017). A cross-country comparison of the relationship between ownership concentration and firm performance: does judicial system efficiency matter? Corporate Governance: The International Journal of Business in Society.

Mohor, A. (2007). Uso de indicadores para evaluar el funcionamiento policial: notas y experiencias para la reforma policial en México. Centro de Estudios en Seguridad Ciudadana.

Naciones Unidas. (2010). Aplicacion eficaz de las directrices de las Naciones Unidas para la prevencion del delito. Salvador.

Pastor, S. (1993). Ah! de la Justicia. Política Judicial y Economía, Madrid, Cívitas. Revista Española de Investigación Criminológica.

Rosales-López. (2008). Economics of court performance: an empirical analysis. European Journal of Law and Economics.

Sandelin, B y G. Skogh. (1986). Property crimes and the police: an empirical analysis of Swedish data. Scandinavian Journal of Economics.

Schepard A. y Bozzomo J. (2003). Efficiency, Therapeutic Justice, Mediation, and Evaluation: Reflections on a Survey of Unified Family Courts. Family Law Quarterly.

Weisburd, D. (2008). Place-based Policing. Police Foundation, Ideas in American Policing. Doi: https://www.publicsafety.gc.ca/lbrr/archives/cnmes-plcng/cn31759-eng.pdf 